\title{
Verðbólguspár og verðbólgumarkmið Seðlabanka Íslands
}

\author{
Guðmundur Guðmundsson ${ }^{1}$
}

\begin{abstract}
Ágrip
Samkvæmt lögum um Seðlabanka Íslands frá 2001 er meginmarkmið hans að stuðla að stöðugu verðlagi. Hagfræðisvið Seðlabankans býr til ársfjórðungslíkan af íslenska hagkerfinu og birtir lýsingu á pví. Par er verðbólgu lýst með Phillips-ferli að viðbættum væntingum. Stýrivextir eru helsta stjórntæki bankans. Peir fylgja Taylorreglu í líkaninu og hefur hún löngum verið í góðu samræmi við raunverulegar vaxtaákvarðanir. Pá tók bankinn upp pá stefnu að birta spár um verðbólgu með stýrivaxtaferil par sem verðbólgumarkmiðið næðist innan priggja ára. Áhrif stýrivaxta á umframeftirspurn og gengi dugðu ekki til pess. Раð hafðist pó með pví að reikna með að verðbólguvæntingar löguðu sig hratt að markmiðinu pó að engin merki væru um slíka hegðun í gögnum um vaxtamuninn. Í ársfjórðungslíkaninu 2009 er vaxtamuninum sleppt, en verðbólguvæntingar metnar með fyrra gildi verðbólgu, reiknaðri spá um verðbólgu eftir tvö ár og beinni tengingu við markmiðið. Petta líkan spáir einnig hraðri leitni að markmiðinu, en uppfyllir ekki lágmarkskröfur um samræmi við fyrirliggjandi verðmælingar.
\end{abstract}

\begin{abstract}
Price stability is the main objective of monetary policy according to the Central Bank Act from 2001. The Research Department of the Central Bank maintains a quarterly model of the Icelandic economy and publishes a concise description of it. Inflation is modelled as an expectations-augmented Phillips curve. The policy rate is the main instrument of the Bank for achieving price stability. It follows a Taylor rule in the model and also in practice most of the time. At this time the bank adopted the policy that its inflation predictions and associated interest rate path should reach the inflation target within three years. The effects of policy rates were inadequate for this, but the target was reached by assuming that expectations would adjust quickly to the target although no sign of such tendency was detectable in their past. The interest rate difference is not included in the model from 2009, but inflation expectations are represented by lagged inflation, expected future inflation in two years and the inflation target. This model also predicts a rapid convergence towards the target, but the fit with observed inflation is inacceptable.
\end{abstract}

JEL flokkun: C53, E52

Lykilhugtök: Hagmælingar, verðbólga

\footnotetext{
1 Guðmundur Guðmundsson er tölfræðingur. Höfundur pakkar gagnlegar ábendingar ritrýnenda tímaritsins.
} 


\section{Inngangur}

Mikið af efni pessarar greinar hefur áður birst í greinum höfundar í ritröðum á vefsíðum Raunvísindastofnunar Háskóla Íslands og Rannsóknastofnunar í fjármálum og hagfræði við Háskólann í Reykjavík. (Guðmundur Guðmundsson, 2008 og 2009). Lýsingar á pjóðhagslíkani Seðlabankans eru birtar á vefsíðu hans. (Ásgeir Daníelsson o.fl., 2006 og 2009). Pessi rit eru öll á ensku.

Við hagfræðideild og hagfræðisvið Seðlabanka Íslands hafa verðbólguspár verið búnar til reglubundið síðan um 1980. Pessar spár hafa stuðst við líkön af sambandi verðbólgu við aðrar hagstærðir, einkum launakostnað og innflutningsverð, metin með tölfræðiaðferðum. Ástæðan til að pessi líkön komu ekki fyrr fram var fyrst og fremst skortur á mælingum á launum. En undir lok 8. áratugarins kom Már Guðmundsson saman nothæfri launaröð og náði hún aftur til ársins 1962. Pjóðhagsstofnun og hagsmunasamtök höfðu áður sett fram verðbólgulíkön með sömu breytum, en metið vægi peirra með hliðsjón af útreikningi Hagstofunnar á vísitölu framfærslukostnaðar og giskað á tímatafirnar. Vægi breytna reyndust svipuð í tölfræðilíkönunum, en tímatafir lengri. (Guðmundur Guðmundsson, 1983).

Ný lög um Seðlabanka Íslands tóku gildi vorið 2001. Samkvæmt peim er Seðlabankinn sjálfstæð stofnun og „Meginmarkmið Seðlabanka Íslands er að stuðla að stöðugu verðlagi. Með sampykki ráðherra er Seðlabankanum heimilt að lýsa yfir tölulegu markmiði um verðbólgu."

Ofangreind ákvæði voru í samræmi við ríkjandi próun í starfsemi seðlabanka erlendis og nutu stuðnings hagfræðinga Seðlabanka Íslands eins og fram kemur í ýmsum greinum peirra frá pessum tíma og síðar. (Már Guðmundsson, 2002, Porvarður Tjörvi Ólafsson, 2007, Pórarinn Pétursson, 2000, 2004, 2005, 2007 og 2009). Nokkrar breytingar voru gerðar á stjórn bankans með lagasetningu árið 2009. Í stað priggja bankastjóra stjórnar peningastefnunefnd hvernig helstu stjórntækjum bankans er beitt, en meginmarkmiðið er óbreytt.

Stýrivextir eru mikilvægasta stjórntæki seðlabanka. Röksemd sem mikið ber á í málflutningi til stuðnings verðbólgumarkmiði er að par sem seðlabanki hafi aðeins yfir einu stjórntæki að ráða eigi hann aðeins að stefna að einu markmiði. (Pórarinn Pétursson, 2007).

Árið 2002 var Pjóðhagsstofnun lögð niður. Gagnasöfnun og útreikningar á pjóðhagsreikningum fluttust til Hagstofunnar en Fjármálaráðuneytið sá um pjóðhagsáætlun fyrir ríkisstjórnina. Seðlabankinn parf mikið á pjóðhagsspám að halda og pað samrýmist illa sjálfstæði hans frá 2001 að notast við pjóðhagsspár sem samdar eru undir handarjaðri fjármálaráðherra. Um líkt leyti og sjálfstæði Seðlabankans var fest í lög hóf hann að búa til pjóðhagslíkan með ársfjórðungsgildum og tók pað í notkun 2006. Fyrsta lýsing á líkaninu birtist 2006 og ný útgáfa 2009. (Ásgeir Daníelsson o.fl., 2006 og 2009). Par eru allar jöfnur sýndar og stuttur texti með hverri. Gögnin sem líkanið er metið eftir eru einnig birt. Líkanið kallast á ensku Quarterly Macroeconomic Model, skammstafað QMM, og verður sú skammstöfun notuð hér. Frá pví að QMM var tekið í notkun hefur pað verið aðaltæki Seðlabankans við verðbólguspár. Par er birt verðbólgujafnan sem notuð er við reikningana og textinn er helsta heimild um hvaða fræði sé stuðst við.

Í inngangi QMM er lýst hlutverki pess í margvíslegum hagrannsóknum og við mat á óvissu. Líkanið parf að fela í sér mat Seðlabankans á mikilvægustu samböndum í hagkerfinu og ná til megindrátta í miðlun áhrifa peningastefnunnar. (Ásgeir Daníelsson o.fl., 2009, bls.6).

Um hagfræðilegan grundvöll QMM segir að hann byggist ekki á nákvæmlega skilgreindri hámörkunarhegðun einkaaðila, heldur styðjist aðallega við leiðréttingarliði, 
metna með mældum gögnum. Samræmi við reynslu og mælingar er pví sett hærra en fullt fræðilegt samræmi samkvæmt skilgreiningu Pagans (2003). Af pví leiðir að ekki er víst að líkanið leiti sjálfkrafa í átt að stöðugri lausn pegar til lengdar lætur. Prjú skilyrði parf að uppfylla til að tryggja samleitni að stöðugu ástandi. Í fyrsta lagi purfa stærðir á nafnverði að vaxa í samræmi við verðbólgumarkmið Seðlabankans. Í öðru lagi purfa raunstærðir að leita í átt að jafnstöðuvexti mögulegrar framleiðslu (sem er summa vaxtarhraða mannfjölda og tækni). Аð lokum parf að tryggja að til lengdar ríki ekki samband milli nafnstærða og raunstærða.(Ásgeir Daníelsson o.fl., 2009, bls.15).

Skilyrðin prjú hafa mikil áhrif á QMM. Miðað við peningastefnu núverandi löggjafar næst ekki jafnvægisástand nema nafnstærðir fylgi markmiði Seðlabankans. Рað er hins vegar ekkert hagfræðilögmál að petta markmið náist. Í síðustu útgáfu QMM er reiknað með að samleitni að slíku jafnvægisástandi hafi ríkt síðan 1994. Grein Ásgeirs Daníelssonar (2009) fjallar um annað skilyrðið, en pað kemur ekki við sögu hér. Priðja skilyrðið var innbyggt í verðbólgujöfnuna, bæði 2007 og 2009, en tekið fram í texta að mikil verðbólga sé pó líklega skaðleg. Sjá líka grein Pórarins Péturssonar (2007).

Í ársbyrjun 2007 var tekin upp ný stefna við mótun verðbólguspár Seðlabankans: „Pjóðhags- og verðbólguspá Seðlabanka Íslands er nú birt með nýjum hætti. Grunnspáin er byggð á stýrivaxtaferli sem sérfræðingar bankans telja að stuðli best að framgangi verðbólgumarkmiðsins. Stýrivaxtaferillinn er valinn með hliðsjón af pví markmiði að verðbólga verði pví sem næst 2²\% \% innan ásættanlegs tíma og haldist stöðug í nánd við verðbólgumarkmiðið eftir pað. Pannig er stuðlað að pví að peningastefnan veiti verðbólguvæntingum trúverðuga kjölfestu.“ (Seðlabanki Íslands, 2007).

Ásgeir Daníelsson o.fl.(2009) lýsa verðbólgujöfnu sinni sem venjulegum Phillips-ferli að viðbættum væntingum og reikna með tímabundnum áföllum vegna raungengis og raunlauna. Sama lýsing var í QMM frá 2006. Mikið hefur verið ritað um pessa gerð verðbólgulíkana síðustu ár, sbr. yfirlitsgrein Porvarðar Tjörva Ólafssonar (2006). Parna er litið á skýringarbreytur eldri líkananna sem viðauka við aðalatriðin sem eru verðbólguvæntingar og eftirspurn. Sama breyta er notuð til að mæla eftirspurn í QMM 2006 og 2009, en meðferð á væntingum er gerólík. Friðrik Már Baldursson og Axel Hall (2008) fjalla um meðferð væntinga í verðbólgulíkönum.

Í QMM fylgja stýrivextir Taylor-reglu sem stýrir verðbólgu í átt að verðbólgumarkmiðinu. Hún dugir pó ekki til að ná pví innan tímaramma birtingarstefnunnar frá 2007 (Friðrik Már Baldursson og Axel Hall, 2008). Petta virðist hafa leitt til pess að í QMM voru teknar inn forsendur um verðbólguvæntingar og tengsl peirra við verðbólgu sem ganga í berhögg við pá yfirlýsingu höfunda að samræmi við reynslu og mælingar sé forgangsatriði við gerð líkansins.

\section{Eitt tæki, eitt markmið}

Fróðlegt er að beita einföldu formlegu líkani að almennri hagstjórn til að skoða peningamálastefnu sem beinist fyrst og fremst að pví að hemja verðbólgu með stýrivöxtum. Leitast er við að hámarka nytjafall, $\mathrm{U}(\mathbf{y})$, par sem y er vigri hentugra breytna til að lýsa U. Mældar hagstærðir eru fjölmargar og sterkt samband milli sumra peirra pannig að mismunandi y mætti nota til að lýsa nokkurn veginn sömu nytjaföllum. Með hliðsjón af áherslu Seðlabankalaganna á verðbólgumarkmið notum við nytjafall og vigra par sem fyrsta stakið í y er verðbólga og gerum ráð fyrir að fyrsta afleiða U(y) m.t.t. y1 sé jákvæð pegar verðbólga er lægri en markmiðið en neikvæð pegar hún er hærri. Tiltæk stjórntæki mynda 
annan vigra, $\mathbf{x}$, og par látum við x1 vera stýrivextina. Ef við gerum ráð fyrir skaplegum föllum breytist nytjafallið um

$$
\Delta \mathrm{U}=\sum_{\mathrm{j}} \frac{\partial \mathrm{U}}{\partial \mathrm{y}_{\mathrm{j}}} \frac{\partial \mathrm{y}_{\mathrm{j}}}{\partial \mathrm{x}_{1}} \Delta \mathrm{x}_{1}
$$

pegar $\mathrm{x}_{1}$ breytist um $\Delta \mathrm{x}_{1}$. Hér er tímapætti hagstjórnarinnar sleppt. Um pessi fræði er fjallað í kennslubókum í hagfræði, t.d. Wickens (2008).

Takmarkanir geta verið á hvernig unnt er að beita stjórntækjum. Slíkum takmörkunum er lýst með sérstökum föllum,

$$
\mathrm{V}_{\mathrm{k}}(\mathbf{y}, \mathbf{x}) \geq 0, \quad \mathrm{k}=1,2, \ldots \text { fjöldi skilyrða. }
$$

Enda pótt stýrivextir séu helsta stjórntæki Seðlabankans eru peir innri breyta í QMM. Líkanið er parna hjálpartæki til að velja hvernig best sé að beita vöxtunum til að ná markmiðum bankans. Jafna peirra fylgir Taylor-reglu, en samkvæmt henni ráðast stýrivextir af framleiðsluspennu og mismuni verðbólgu og verðbólgumarkmiðs. Miðað við áhrif vaxta á gengi, neyslu og fjárfestingu í QMM er fyrsta afleiða $\mathrm{y}_{1}$ m.t.t. $\mathrm{x}_{1}<0$ svo að vaxtahækkun dregur úr verðbólgu. Samkvæmt stefnu bankans um birtingu verðbólguspár er látið nægja að ná verðbólgumarkmiðinu innan ásættanlegs tíma. Petta veitir nokkurt svigrúm við tímasetningu vaxtabreytinga sem nýtt er til að forðast sveiflur í framleiðsluferlinu.

Samkvæmt ofangreindum forsendum getur Seðlabankinn beitt stýrivöxtum til að poka verðbólgu í rétta átt. En pað tryggir ekki að nytjafallið hækki. Stýrivextir hafa áhrif á fjölda hagstærða, p.e.a.s. $\Delta \mathrm{x}_{1}$ breytir fleiri stökum y en yı. Рað er pví ekki er gefið að U hækki pó að y1 hreyfist í rétta átt. Fleiri stjórntæki en stýrivextir hafa áhrif á verðbólgu svo að betra gæti verið að beita einhverjum peirra til að breyta henni. คað er heldur ekki útilokað að einhver skilyrði, t.d. um gengi eða erlendar skuldir, ættu heima meðal $\mathrm{V}_{\mathrm{k}}(\mathbf{y}, \mathbf{x})$ og kæmu í veg fyrir að unnt væri að notast við vextina til að ná niður verðbólgu.

Frá sjónarhóli stærðfræði pyrftu að gilda pröng skilyrði um eiginleika falla sem parna koma við sögu til að peningamálastefna sem miðast við verðbólgumarkmið, með stýrivextina eina að vopni, væri nálægt bestu stjórnarháttum. Að öðrum kosti væri hætt við að petta leiddi til árekstra við heildarmarkmið hagstjórnar. Hunt (2006) bendir á að aðstæður til að hemja verðbólgu innan pröngra marka séu óvenju erfiðar á Íslandi. En eins og fram kemur hjá Pórarni Péturssyni (2005) hefur petta víða gengið vel.

Vandkvæði við hagstjórn Seðlabankalaganna hefur borið hátt í umræðum um efnahagsmál eftir hrun bankakerfisins. Verðbólga fór yfir markmið bankans 2004 og hefur verið pað síðan. Hann brást við í samræmi við landslög og Taylor-reglu og barðist gegn verðbólgunni með háum stýrivöxtum. Petta leiddi til hás gengis og hafði sterk áhrif á viðskiptajöfnuð og atvinnurekstur.

\section{Eldri verðbólgulíkön}

Í dæmum sem hér fara á eftir verður notað gagnasafn QMM frá maí 2009 og sömu nöfn fyrir breyturnar. Par má líka finna nánari lýsingu á einstökum röðum. Mældar raðir eru táknaðar með stórum bókstöfum og lógaritmagildi með litlum. Tími er táknaður með t og miðast við ársfjórðungsgildi, $\Delta \mathrm{x}_{\mathrm{t}}=\mathrm{xt}_{\mathrm{t}}-\mathrm{X}_{\mathrm{t}-1}$ og $\Delta 4 \mathrm{X}_{\mathrm{t}}=\mathrm{x}_{\mathrm{t}}-\mathrm{X}_{\mathrm{t}-4}$.

Pegar íslenskir áhrifamenn - ráðherrar, atvinnurekendur, verkalýðsleiðtogar og seðlabankastjórar - lýsa skoðunum sínum á verðbólguhorfum vitna peir einkum til ástands 
gengis- og kjaramála peim til stuðnings. Verðbólgulíkön voru löngum á svipuðum nótum og oft af gerðinni

$$
\Delta \text { cpit }=\theta_{0}+\sum_{\mathrm{j}=1} \theta_{\mathrm{pj}} \Delta \mathrm{cpit}_{\mathrm{t}-\mathrm{j}}+\sum_{\mathrm{j}=0} \theta_{\mathrm{uj}} \Delta \mathrm{ulct}_{\mathrm{t}-\mathrm{j}}+\sum_{\mathrm{j}=0} \theta_{\mathrm{pm}, \mathrm{j}} \Delta \mathrm{pm}_{\mathrm{t}}+\varepsilon_{\mathrm{t}}
$$

par sem stikar eru táknaðir með $\theta$. Breytur líkansins eru:

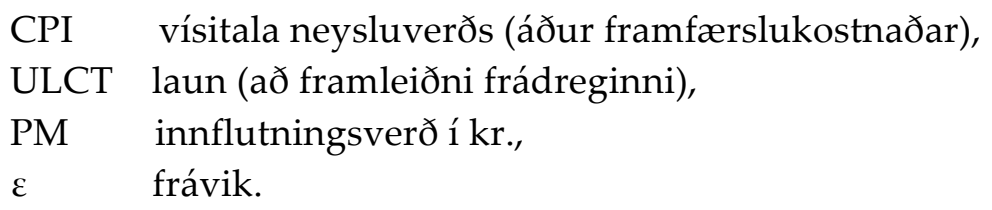

Lítill en marktækur ávinningur var af pví að bæta leiðréttingarliðunum (ulctt-1 - cpit-1) og (pmt-1 - cpit-1) við skýribreytur fyrri líkana. Sterk rök frá hagfræði og tímaraðafræðum eru fyrir pví að hafa pá með. Hins vegar eru parna vandkvæði með mælingar. Ofangreindar raðir eru allar vísitölur. Breytingar á magni og gæðum peirra pátta sem par koma við sögu valda mæliskekkjum yfir langan tíma sem ógerningur er að komast algerlega hjá. Leiðréttingarliðirnir eru miklu næmari fyrir pessum skekkjum en fyrsti mismunur. Meginhagfræði pessara líkana var að pau lýstu pví hvernig kostnaðarhækkanir bærust út í verðlagið.

Í líkönum af gerð jöfnu (1) sem metin voru með gögnum fyrir pjóðarsáttina 1990 var $\theta_{0}$ $\approx 0$, summa annarra stika $\approx 1$, staðalfrávik skekkjunnar $\approx 0,015$ og $\mathrm{R}^{2} \approx 0,85$. (Guðmundur Guðmundsson, 1990).

Pegar metið er með gögnum frá sama tímabili og í QMM 2009, frá 1994:1 til 2006:3, fæst hins vegar $\mathrm{s}=0,0053$ og $\mathrm{R}^{2}=0,51$, (V1 í jöfnuviðauka). Fastinn er 0,0042 með staðalfrávik 0,0013 og summa annarra stika er 0,496. Ef verðlag, launakostnaður og innflutningsverð hafa sömu leitni og verða sístæðar með einni diffrun, p.e.a.s. I(1) raðir, lýsir petta líkan sístæðri röð með meðalgildi 0,0083 sem svarar til 3,4\% árlegrar verðbólgu. Í líkani með fastann 0 og summu annarra stika 1 er hins vegar ekkert fast meðalgildi. Petta er í samræmi við verðbólgupróunina fyrir pjóðarsátt pegar skiptust á tímabil með mjög mishárri verðbólgu og I(1) líkan átti illa við. (Guðmundur Guðmundsson, 2002).

Meginskýringin á lægra staðalfráviki líkans jöfnu (1) eftir pjóðarsátt er að bæði verðbólga og breytingar á henni milli ársfjórðungsgilda eru lægri en fyrir 1990. Ástæðan til pess hvað líkanið skýrði hátt hlutfall af breytingum verðbólgunnar fyrir pjóðarsátt var að laun og innflutningsverð í krónum hækkuðu miklu meira en nam hagvexti. Рað var pví lítið svigrúm til annars en koma hækkunum út í vöruverð. (Samkvæmt kostnaðarkenningunni var ástæðan fyrir tímatöfum að Hagstofan mælir smásöluverð, en nokkur tími getur liðið frá pví að laun eða innflutningsverð hækka par til varan birtist í búð).

Líkan jöfnu (1) skýrir nú aðeins rúman helming af dreifni $\Delta$ cpi pó að staðalfrávikið sé lægra en fyrir pjóðarsátt. Petta stafar einkum af pví að breytingar á verðbólgu milli ársfjórðunga eru nú minni. Frávik vegna mæliskekkju og áhrifa sem líkanið nær ekki til vega hlutfallslega pyngra en áður. Ég held að skýringin á lægri stikum breytinga á launakostnaði og innflutningsverði sé að hækkun peirra hefur færst nær hækkunum á raunstærðum. Seljendur hafa pví meira svigrúm til að hagræða tímasetningu á verðhækkunum vegna breytinga á kostnaði. Aukið framboð á lánsfé jók líka möguleika á að velja tímasetningu 
verðbreytinga. Samband kostnaðarhækkana við verðbólgu verður pví óreglulegra enda pótt pær rati eftir sem áður einhverntíma út í vöruverð.

Líkan jöfnu (1) lýsir föstu sambandi verðbreytinga við breytingar skýristærðanna. Frávikin eru eignuð mæliskekkjum háðu breytunnar og utanaðkomandi truflunum, óháðum skýribreytum líkansins. Líkanið er ekki rétt lýsing á óreglu sem stafar af mæliskekkju óháðra breytna eða breytilegum tímamuni peirra og háðu breytunnar, svo að kvaðratfrávik jöfnunnar verður lægra með pví að láta fastann um að skýra helming verðbólgunnar. Раð er hægt að setja fram líkan að samböndum með breytilegum tímamuni, en litlir möguleikar á að meta pað með peim gögnum sem hér er kostur á (Guðmundur Guðmundsson, 1998).

\section{Líkön QMM}

Í pjóðhagslíkani Seðlabankans sem birtist í mars 2007 (Ásgeir Daníelsson o.fl., 2006) er verðbólgulíkan metið með gögnum frá 1994:1-2004:4. Ég sýni pað hér metið með gögnum frá 1994:1-2006:3, en útkoman er svipuð.

$$
\begin{aligned}
& \Delta \mathrm{cpi}_{\mathrm{t}}=0,766 \mathrm{INFE}_{\mathrm{t}} / 4+0,051 \Delta \mathrm{pm}_{\mathrm{t}}+0,055 \Delta \mathrm{pm}_{\mathrm{t}-1}+0,127 \Delta \mathrm{uclt}_{\mathrm{t}-1}+0,097 \mathrm{GAPAV}_{\mathrm{t}-1}, \\
& (15,3) \\
& (2,4)
\end{aligned}
$$

INFE táknar verðbólguvæntingar, metnar með vaxtamuni óverðtryggðra og verðtryggðra skuldabréfa með $2 \%$ áhættupóknun vegna verðbólguáhættu. GAPAV stendur fyrir framleiðsluspennu, mælikvarða á eftirspurn.

GAPAV er reiknað pannig að langtímameðaltal pess verður 0 og stikar annarra breytna eru pvingaðir til að vera samtals 1 vegna kröfunnar að ekkert langtímasamband geti ríkt milli verðbólgu og raunstærða. (Reiknað er með аð launakostnaður, innflutningsverð og verðbólguvæntngar hafi sömu langtímaleitni og vísitala neysluverðs).

Breytur verðbólguvæntinga og framleiðsluspennu í jöfnu (2) eru ekki í eldri líkönunum, en í jöfnu (2) er hvorki fasti né tafið gildi háðu breytunnar $\Delta$ cpi. Áður var ekki hægt að meta framleiðsluspennu á sama hátt og nú par sem pjóðhagsstærðir voru aðeins mældar árlega. Ef $\mathrm{GAPAV}_{\mathrm{t}-1}$ er bætt við skýribreytur jöfnu (1) og metið með gögnum frá sama tímabili og jafna (2) verður staðalfrávikið 0,00477, (jafna V2 í viðauka).

Samkvæmt jöfnu (2) mætti í fljótu bragði ætla að verðbólguvæntingarnar INFE væru mikilvæg stærð til að skýra breytingar verðbólgu eftir 1994. Svo er ekki. Hár stiki og t-gildi stafa af pví að enginn fasti er í jöfnunni. En fái hann að vera með verður stiki INFE varla marktækur, (jafna V3 í viðauka). Fasta er hægt að túlka sem væntingar um fasta verðbólgu og sé reiknað með einsleitni má meta stærð hennar.

Stýrivextir Taylor-reglunnar teyma verðbólgu í átt að markmiði Seðlabankans, en of hægt til að tryggja að pað náist jafn hratt og bankinn vill birta í sínum spám, (Friðrik Már Baldursson og Axel Hall, 2008). Í útgáfu QMM 2007 var pví náð með pví að skilgreina að á spátímabilinu fylgdi INFE jöfnunni

$$
\mathrm{INFE}_{\mathrm{t}}=0,3 \mathrm{INFE}_{\mathrm{t}-1}+0,3 \mathrm{INF}_{\mathrm{t}-1}+0,4 \mathrm{IT} \text {, }
$$

par sem $\mathrm{INF}_{t}$ er árshækkun verðbólgu og IT verðbólgumarkmiðið. Petta dugir til að verðbólguspáin taki á rás að markmiðinu og nái pví á tilsettum tíma, en á sér enga stoð í 
raunverulegri hegðun INFEt á tímabilinu eftir að verðbólgumarkmiðið kom til sögunnar. (Guðmundur Guðmundsson, 2008).

Ný útgáfa QMM birtist í febrúar 2009, (Ásgeir Daníelsson o.fl., 2009). Par er búið að skipta um jöfnu fyrir vísitölu neysluverðs og er hún nú

$$
\Delta_{4} \mathrm{cpi}_{\mathrm{t}}=0,625 \Delta_{4} \mathrm{cpi} \mathrm{i}_{\mathrm{t}-1}+0,178 \Delta_{4} \mathrm{cpi} \mathrm{i}_{\mathrm{t}+8}+(1-0,625-0,178) \log \left(1+\mathrm{IT}_{\mathrm{t}}\right)+0,111 \Delta_{4} \text { rexm } \mathrm{t}-1
$$

$$
+0,077 \Delta_{4}\left(\text { ulct }_{\mathrm{t}-4}-\text { cpit-4 }\right)+0,083 \mathrm{GAPAV}_{\mathrm{t}-1},
$$

$$
\mathrm{R}^{2}=0,883 ; \quad \mathrm{s}=0,0069 \text {. }
$$

par sem REXM er raungengi innflytjenda.

Jafnan er metin með almennri vægjaaðferð, GMM, með gögnum frá 1994:1 - 2006:3. Verðbólgan er nú ekki mæld milli ársfjórðunga, heldur yfir heilt ár og aðrar breytur á sama hátt. Í stað vaxtamunar óverðtryggðra og verðtryggðra skuldabréfa er verðbólguvæntingum nú skipt í prjá pætti. Einn horfir aftur og er metinn með $\Delta_{4}$ cpit-1, annar fram, metinn með $\Delta_{4}$ cpi $_{++8}$ og sá priðji er verðbólgumarkmiðið $\log \left(1+\mathrm{IT}_{\mathrm{t}}\right)$. Áhrifum breytinga á launum og raungengi er komið fyrir í liðum með langtímameðaltal 0. Pannig eru aðeins stikar verðbólguvæntinga pvingaðir til að vera samtals 1 vegna skilyrða um ekkert langtímasamband verðbólgu við raunstærðir og sístæða verðbólgu. Pessi framsetning á væntingum í jöfnu cpit, með stikann 0,20 á verðbólgumarkmiðinu, tryggir að pað næst innan viðunandi tíma samkvæmt stefnu Seðlabankans um birtingu á verðbólguspám. Stiki verðbólgumarkmiðsins hefur verið túlkaður sem mælikvarði á traust á peningamálastefnuna, (Friðrik Már Baldursson og Axel Hall, 2008).

Tafin gildi cpit eru gefnar stærðir í verðbólgujöfnum QMM. Jöfnur (2) og (3) má pví báðar umrita pannig að háða breytan sé cpit með pví að flytja cpit-1 á hægri hliðí jöfnu (2) og cpit-4 í jöfnu (3). Petta hefur engin áhrif á staðalfrávik jafnanna né stikamat.

Раð er eftirtektarverð ákvörðun að hætta við jöfnu fyrir lógaritma vísitölu neysluverðs með staðalfrávik 0,00485 og taka upp aðra, sem að mestu styðst við sömu mælingar, með staðalfrávik 0,0069. Frávik beggja jafna fylgja normaldreifingu pokkalega svo að pað er $(0,0069 / 0,00485)^{51}=64 \times 10^{6}$ sinnum líklegra að fá mældu gildi vísitölu neysluverðs 1994:12006:3 ef íslenska hagkerfið fylgir QMM frá 2007 en nýju jöfnunni. Önnur vísbending um hve illa verðbólgujafna QMM 2009 líkir eftir mælingunum er að prátt fyrir fimm metna stika og fjórar skýringarbreytur auk fyrri gilda vísitölunnar fylgir hún gögnunum verr en tveggja stika líkön sem eingöngu styðjast við fyrri gildi cpit. (Líkönin eru sýnd í jöfnum V4-V6 í viðauka).

Mér hefur ekki tekist að líkja nákvæmlega eftir mati QMM 2009 á verðbólgujöfnunni, fæ heldur hærra staðalfrávik en QMM. En 0,0069 er meira en nógu hátt til að gera pau ummæli formálans, að samræmi við mælingar hafi verið forgangsatriði við líkanssmíðina, að öfugmæli um verðbólgujöfnuna.

Í líkönum með framsýnar væntingar er fall af óháðum breytum notað til að spá framtíðargildi háðu breytunnar og sama fall er skýristærð fyrir háðu breytuna. Pessi pvingun á stika óháðra breytna leiðir til pess að líkön með framsýnum væntingum geta ekki fylgt háðu breytunni jafn nákvæmlega og líkön par sem engin pvingun væri á óháđu breytunum. Tölfræði er beitt til að prófa hvort munurinn sé marktækur. Petta er pó ekki skýringin á háu 
staðalfráviki verðbólgujöfnu QMM 2009. Munurinn á líkönum með og án framsýnna væntinga er smámunir miðað við pað sem par er á ferðinni. Dæmi um petta má sjá hjá Pórarni Péturssyni (1998).

Ég geri ráð fyrir að hagfræðileg sjónarmið hafi ráðið pví að skipt var um verðbólgujöfnu í QMM 2009. Meginástæðan fyrir pví hve illa nýja líkanið fellur að mælingunum er hins vegar að par er stuðst við mismun ársfjórðungsgilda milli ára. Eins og Box og Jenkins (1973) bentu á getur pað verið góð leið til að fást við breytilega árstíðasveiflu. En pað eru engin merki um árstíðasveiflu í ársfjórðungsgildum vísitölu neysluverðs eða frávikum líkansins. Hins vegar dregur aðgerðin mikla tilviljunarkennda óreglu inn í líkanið.

Flest verðbólgulíkön, par á meðal QMM, fara með lógaritma verðraða sem I(1) breytu. Lítum á einfalt slembigöngulíkan:

$$
\mathbf{x}_{\mathrm{t}}=\mathrm{c}+\mathbf{X}_{\mathrm{t}-1}+\varepsilon_{\mathrm{t}}
$$

eða

$$
\Delta \mathrm{x}_{\mathrm{t}}=\mathrm{c}+\varepsilon_{\mathrm{t}}
$$

par sem Xt er I(1) breyta, c er fasti og $\varepsilon$ t frávik. Pá er

$$
\Delta 4 X_{t}=4 c+\varepsilon_{t}+\varepsilon_{t-1}+\varepsilon_{t-2}+\varepsilon_{t-3 .} .
$$

Miðað við óháð frávik er dreifni $\Delta_{4} \mathrm{X}_{\mathrm{t}}$ fjórum sinnum stærri en dreifni $\Delta \mathrm{x}_{\mathrm{t}}$ og fylgnistuðull $\Delta_{4 \mathrm{X}_{\mathrm{t}}}$ og $\Delta_{4 \mathrm{X}-1}$ er 0,75 .

Innbyggð fylgni $\Delta_{4}$ cpit og $\Delta_{4}$ cpit-1 hefur sterk áhrif á verðbólgulíkan jöfnu (3) par sem $\Delta_{4}$ cpit-1 er veigamesti liðurinn á hægri hlið jöfnunnar. Í texta QMM frá 2009 er $\Delta_{4}$ cpit-1 túlkað sem væntingar er styðjist við fortíð og $\Delta_{4}$ cpit+8 sem framsýnar væntingar.

Pað réttlætir ekki valið á tímamuni að Seðlabankalögin miði verðbólgu við verðhækkun yfir eitt ár. Pegar verðbólguspá er sett fram eru öll liðin gildi verðsins pekkt. Рað er bara óvissan um framtíðargildi sem ræður gæðum spár um árshækkun. Ekki kannast ég heldur við nein hagfræðileg rök fyrir pví að nota mismun yfir fjóra ársfjórðunga fremur en t.d. einn, tvo eða sex ef engin árstíðasveifla er fyrir hendi. Pessir valkostir leiða til afar ólíkra gilda á verðbólgumælingu, tafinni um einn ársfjórðung, sem túlkuð er sem væntingar. Sé "væntingunum" $\Delta$ cpit-1 bætt við á hægri hlið jöfnu (2) fá pær stikann 0,078 með t-gildi 0,6. Ekki verður heldur séð að valið á verðbólgu eftir tvö ár sem viðmiðun um framsýnar væntingar styðjist við hagfræði eða venju. En pessir liðir, tengdir við verðbólgumarkmiðið með kröfunni um einsleitni, stýra verðbólgu að markmiðinu í spám sem fylgja jöfnunni.

QMM 2007 og 2009 nota gerólíkar stærðir til að tákna væntingar í „Phillips-ferlum að viðbættum væntingum”. Athyglisvert er að beinar mælingar á væntingum sem Seðlabankinn hefur staðið fyrir og birtir reglulega í Hagtölum sínum eru ekkert notaðar í verðbólgulíkönunum. Væntingarnar virðast fremur miðast við stöðu peirra í pessari gerð líkana en tengingu við mældar stærðir. Frá tölfræðisjónarmiði væri pá nærtæk rannsóknaraðferð að setja upp líkan að Phillips-ferili samkvæmt hagfræðinni, par sem „væntingar" væru skilgreindar sem ástandsbreyta. Tengsl hennar við mældar stærðir og tölfræðilegir eiginleikar væru síðan ákvörðuð í sérstakri jöfnu. Pessi framsetning hentar vel til að kanna möguleika á að nýta upplýsingar um væntingar í mældum röðum. (Guðmundur Guðmundsson, 2008).

Í lýsingu QMM 2009 á verðbólgujöfnunni er tekið fram að tölfræðipróf sampykki skilyrðið að summa stika $\Delta_{4} \mathrm{cpit}_{-1}, \Delta_{4} \mathrm{cpi} \mathrm{i}_{+8}$ og $\log (1+\mathrm{IT})$ sé 1 í jöfnu (3). Jafnan er metin með gögnum frá 1994, en verðbólgumarkmiðið kom fyrst til sögunnar með Seðlabankalögunum 
2001. Skilyrðinu er hafnað ef aðeins er stuðst við gögn frá pví að lögin tóku gildi. (Metið með aðferð minnstu kvaðrata eða tveggja prepa mati).

\section{$5 \quad$ Niðurstöður}

Undanfarin ár hafa Verðbólguspár Seðlabankans einskorðast við Phillips-ferils líkön par sem væntingar eru meginpáttur. Enda pótt líkön af pessari gerð njóti nú mikillar hylli eru pau engan veginn óumdeild eins og fram kemur í yfirlitsgrein Porvarðar Tjörva Ólafssonar (2006), m.a. hefur pótt skorta á samræmi við mælingar (Bårdsen o.fl., 2005). Jafnan í QMM 2007 féll sæmilega að mælingunum, en síst betur en líkön par sem litið er svo á að laun og innflutningsverð séu meginskýring verðbólgu og væntingum er alveg sleppt.

Annar meginpáttur í vali á jöfnum í verðbólguhluta QMM er tengslin við lögbundið hlutverk Seðlabankans að stuðla að stöðugu verðlagi. Liður í pví er að birta spár par sem verðbólgumarkmið bankans næst á ásættanlegum tíma. Eins og fram kemur í rannsókn Friðriks Más Baldurssonar og Axels Hall (2008) tókst petta ekki með verðbólgujöfnu og Taylor-reglu QMM 2007, heldur purfti einnig að gefa sér að væntingarnar löguðu sig hratt að markmiðinu og pá fylgdi verðbólgan í kjölfarið. Spánni var beinlínis ætlað að stuðla að pví að væntingar löguðu sig að markmiðinu, en engin merki um slíka hegðun var að finna í gögnum sem notuð voru við matið.

Í QMM 2009 hefur verið skipt um verðbólgujöfnu. Hröð aðlögun væntinga og verðbólgu að markmiðinu er nú innbyggð í sjálfa verðbólgujöfnuna og pví reiknað með að hún hafi verið fyrir hendi frá upphafi gagnatímabilsins, 1994, en ekki aðeins eftir að spáin er sett fram eins og gert var í QMM 2007. Nýja jafnan uppfyllir ekki lágmarkskröfur um samræmi milli líkans og mælinga. Ástæðan til að bankinn tók hana upp virðist tengjast viðleitni til að auka framsýni og skynsamlegar væntingar í QMM, (Ásgeir Daníelsson o.fl. 2009). Jafnframt pví að birta grunnspá sína um verðbólgupróun sýnir Seðlabankinn oft fráviksdæmi til að skýra skekkju sem upp gæti komið vegna óvissu um próun annarra hagstærða sem spáin styðst við. Par er hins vegar ekkert fjallað um stærsta óvissupáttinn í verðbólguspám hans sem er forsendurnar um áhrif væntinga og próun peirra.

Athyglisverð skýring á vali á jöfnum er í inngangi lýsingarinnar á QMM: “Mikilvægt er að hafa í huga að jöfnur líkansins eru mótaðar sem hluti af heildarbyggingu QMM. Val á einstökum jöfnum sem metnar eru með mælingum, og breytum sem par eru hafðar með, ræðst pví af heildarbyggingu líkansins. Ennfremur að val á tiltekinni jöfnu og skammtímaog langtíma takmörkunum sem par er beitt ræðst ekki aðeins af tölfræðilegum ályktunum og hagfræðirökum, heldur einnig af áhrifunum á heildar hermunareiginleika QMM. Pað er pví ekki víst að sérhver jafna líkansins sé besta einnar jöfnu mat á viðkomandi breytu, heldur ætti að túlka hana innan ramma QMM." (Ásgeir Daníelsson o.fl., 2006 og 2009, bls. 16).

Með hliðsjón af lýsingu á notkun QMM sem vísað var til í Inngangi geta ýmsar eðlilegar ástæður legið til pess að víkja frá metnum jöfnum, t.d. við framreikninga ef ástæða er til að ætla að aðstæður hafi breyst frá tímabilinu sem notað er við matið. Við könnun á mikilvægum breytum líkansins gæti verið pægilegt og meinlaust að nota einfaldaða mynd af einhverjum öðrum breytum.

Enda pótt skilyrðið að ekki ríki langtímasamband milli verðbólgu og raunstærða sé ekki óvéfengjanlegt hefur pað svo sterka stöðu í hagfræði að ekkert er athugavert við að búa svo um hnúta í QMM að pað sé uppfyllt. Engin pörf er pó á að grípa til verðbólgujöfnu QMM 2009 til pess. Öðru máli gegnir um skilyrðið að verðbólga nái jafnvægi við verðbólgumarkmið Seðlabankans, hvað pá ef hert er á pví svo að markmiðið náist á 
skömmum tíma. QMM er hentugt tæki til að kanna hvaða skilyrði purfi að uppfylla til að ná markmiðinu á tilteknum tíma og hvaða áhrif pað hafi á aðrar hagstærðir. En pað er ekkert hagfræðilögmál að petta takist.

Pví fer fjarri að unnt sé að réttlæta hvaða val á jöfnum sem er til að uppfylla óskir höfunda QMM um eiginleika líkansins. Skilgreining Karls Popper (1968) á muni vísinda og gervivísinda hefur hlotið víðtæka viðurkenningu. Samkvæmt henni eru vísindalegar kenningar eða tilgátur hrekjanlegar; pað gætu komið fram gögn eða röksemdir sem sýndu fram á að pær væru rangar. Styrkur vísindakenninga felst í pví að standast próf sem hefðu getað hrakið pær.

Í QMM er safn af hagfræðikenningum sett fram sem jöfnur. Pær eru ekki metnar sameiginlega, heldur hver í sínu lagi með viðurkenndum tölfræðiaðferðum sem veita hlutlægar aðferðir til að prófa jöfnurnar gegn öðrum kenningum. Ofangreind lýsing á jöfnuvali í QMM virðist hafna pessum aðferðum til að prófa hagfræði líkansins. Mér er ekki ljóst hvaða mælikvarði á „heildar hermunareiginleika QMM“ á að koma í staðinn fyrir kvaðratsummur og sennileikaföll.

Раð er gott og gilt sjónarmið að velja Taylor-reglu með hliðsjón af pví hvernig hún verkar í QMM. Hún er ekki lýsing á eiginleikum hagkerfisins, heldur sýnir hvernig höfundar QMM telja að Seðlabankinn ætti að bregðast við pví sem par gerist. Frá síðari hluta 2002 fram að bankahruni fóru vaxtaákvarðanir bankans nærri Taylor-reglu QMM.

Verðbólgujafnan er hins vegar hluti af lýsingu QMM á hagkerfinu. Pekking á verðbólgu er takmörkuð og hún er stöðugt rannsóknarefni. Hraði aðlögunar að verðbólgumarkmiði Seðlabankans er ekki gildur mælikvarði á gæði verðbólgulíkans. Hann mælir hvernig líkanið fellur að óskum stuðningsmanna peningastefnunnar en ekki hve vel pað líkir eftir íslensku hagkerfi.

Mikilvæg ástæða til að peningastefna Seðlabankalaganna 2001 var tekin upp var að Seðlabankinn réð ekki við að halda gengi krónunnar innan fastra marka pegar engar hömlur voru á fjármagnsflutningum milli landa. Verðbólgumarkmið átti að koma í stað gengisfestu.

Reynslan og ársfjórðungslíkan Seðlabankans af íslenska hagkerfinu benda til að einir séu stýrivextir ekki nægilega öflugt meðal við verðbólgu og geti haft slæmar aukaverkanir. Ef verðbólgumarkmið á að leysa fastgengisstefnu af hólmi purfa fleiri en Seðlabankinn að taka beinan pátt í að ná pví.

\section{Heimildir}

Ásgeir Daníelsson, Lúðvík Elíasson, Magnús F. Guðmundsson, Björn A. Hauksson, Ragnhildur Jónsdóttir, Porvarður T. Ólafsson og Pórarinn G. Pétursson. (2006). A Quarterly Macroeconomic Model of the Icelandic Economy. Central Bank of Iceland. Seðlabanki Íslands, Working Paper Nr. 32.

Ásgeir Daníelsson, Magnús F. Guðmundsson, Svava J. Haraldsdóttir, Porvarður T. Ólafsson, Ásgerður Ó. Pétursdóttir, Pórarinn G. Pétursson og Rósa Sveinsdóttir. (2009). A Quarterly Macroeconomic Model of the Icelandic Economy. Central Bank of Iceland. Seðlabanki Íslands, Working Paper Nr. 41.

Box, G.E.P. og Jenkins, G.M. (1973). Some comments on a paper by Chatfield and Prothero and on a review by Kendall. J.R. Statist. Soc. A, 136, 337-345.

Bårdsen, G., Eitrheim, Ø., Jansen, E.S. og Nymoen, R. (2005). The Econometrics of 
Macroeconomic Modelling. Advanced Texts in Econometrics. Oxford University Press, Oxford:U.K.

Friðrik M. Baldursson og Axel Hall. (2008). Out of reach? Convergence to an inflation target in the Central Bank of Iceland's macroeconomic model. Tímarit um viðskipti og efnahagsmál, Special issue 2008, 83-106.

Guðmundur Guðmundsson. (1983). Tölfræðikönnun á verðbólgu á Íslandi árin 1962-1981. Fjármálatíđindi 30, 40-53.

Guðmundur Guðmundsson. (1990). Tölfræðikönnun á verðbólgu á Íslandi árin 1962-1989. Fjármálatíđindi 37, 43-53.

Guðmundur Guðmundsson. (1998). A model of inflation with variable time lags. Seðlabanki Íslands, Working paper Nr. 2.

Guðmundur Guðmundsson. (2002). Samband verðbólgu við laun og innflutningsverð. Fjármálatíđindi, 49/2, 23-34.

Guðmundur Guðmundsson. (2008). Statistical Analysis of Models of Inflation in Iceland. Raunvísindastofnun Háskóla Íslands, RH-13-2008.

Guðmundur Guðmundsson. (2009). Inflation modelling at the Central Bank of Iceland. RU Rannsóknarstofnun í fjármálum og hagfræði. Working papers 2009-5.

Hunt, B. (2006). Simple efficient policy rules and inflation control in Iceland. Central Bank of Iceland. Working paper Nr. 30.

Már Guðmundsson. (2002). Verkefni og starfshættir nútíma seðlabanka. Peningamál 4, 80-89.

Pagan, A. (2003). Report on modelling and forecasting at the Bank of England. Bank of England Quarterly Bulletin, Spring, 1-29.

Phillips, A.W. (1958). The relationship between unemployment and the rate of change in money wages in the United Kingdom, 1861-1957. Economica, 25, 283-299.

Popper, K.R. (1968). The logic of scientific discovery. London:Hutchinson \& Co.

Seðlabanki Íslands. (2007). Peningamál 29, 6-7.

Wickens, M. (2008). Macroeconomic Theory. Princeton University Press.

Porvarður T. Ólafsson. (2006). The new Keynesian Phillips curve: in search of improvements and adaption to the open economy. Central Bank of Iceland. Working paper Nr. 31.

Porvarður T. Ólafsson (2007). Birting eigin stýrivaxtaspár eykur áhrifamátt peningastefnu seðlabanka. Peningamál, 29, 71-86.

Pórarinn G. Pétursson. (1998). Price determination and rational expectations. International Journal of Finance and Economics, 3, 162-176.

Pórarinn G. Pétursson. (2000). Nýjar áherslur í starfsemi seðlabanka: Aukið sjálfstæði, gagnsæi og rekningsskil gerða. Peningamál 5, 45-57.

Pórarinn G. Pétursson. (2004). Útfærsla verðbólgumarkmiðsstefnu víða um heim. Peningamál, 18, 57-85.

Pórarinn G. Pétursson. (2005). Inflation targeting and its effects on macroeconomic performance. SUERF Studies 2005/5.

Pórarinn G. Pétursson. (2007). Hlutverk peningastefnunnar. Peningamál 31, 71-75.

Pórarinn G. Pétursson. (2009). Does inflation targeting lead to excessive exchange rate volatility? Seðlabanki Íslands. Working Paper Nr. 43. 


\section{Jöfnuviðauki}

Hér verða sýndar tölulegar útkomur ýmissa metinna líkana sem getið er í greininni. Tímabilið sem háða breytan nær yfir er 1994:1-2006:3. Tákn breytna eru eins og í QMM og gögn úr QMM safninu frá maí 2009.

Stikar jöfnu (1) eftir pjóðarsátt (1994:1-2006:3)

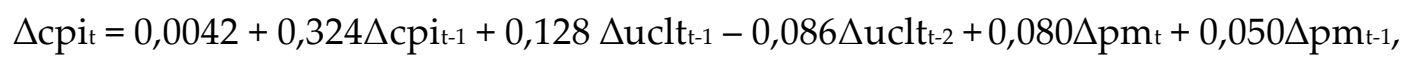

$$
\mathrm{R}^{2}=0,507 ; \quad \mathrm{s}=0,00529 \text {. }
$$

Framleiðsluspennu bætt við jöfnu (1):

$$
\begin{aligned}
& \Delta \text { cpit }=0,0065+0,154 \Delta \text { cpit-1 }+0,100 \Delta \text { ulct }_{t}-0,105 \Delta \text { ulct }-1+0,069 \Delta \text { pm }_{\mathrm{t}}+0,057 \Delta \text { pmt }-1 \\
& (4,8) \quad(1,2) \quad(2,2) \quad(2,2) \quad(3.3)
\end{aligned}
$$

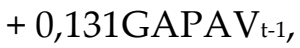

$$
\begin{aligned}
& (4,7) \\
& \mathrm{R}^{2}=0,600 ; \quad \mathrm{s}=0,00477 \text {. }
\end{aligned}
$$

Verðbólgulíkan QMM 2007 að viðbættum föstum verðbólguvæntingum. Pvinguð einsleitni.

$$
\begin{aligned}
& \Delta \text { cpit }_{t}=0,519 \text { INFE }_{\mathrm{t}} / 4+0,259 \mathrm{e}+0,110 \Delta \mathrm{ulct}_{\mathrm{t}-1}+0,056 \Delta \mathrm{pm}_{\mathrm{t}} \\
& (1,5) \quad(0,8) \quad(2,3) \\
& +0,056 \Delta \mathrm{pm}_{\mathrm{t}-1}+0,131 \mathrm{GAPAV}_{\mathrm{t}-1}, \\
& (2,6) \quad(3,1) \\
& \text { e =0,010 }(T=2,3) \quad(\text { fastar verðbólguvæntingar }) \\
& \mathrm{R}^{2}=0,582 ; \quad \mathrm{s}=0,00488 \text {. }
\end{aligned}
$$

Tímaraðalíkön vísitölu neysluverđs án skýringarbreytna

Við líkanasmíðina er beitt peim vinnubrögðum að byrja með líkan með mörgum töfðum gildum cpit á hægri hlið en tína síðan út ómarktækt gildi. Aðeins lokaútgáfan er sýnd hér. Ópvingað mat:

$$
\begin{aligned}
& \text { cpit }=0,0048+1,238 \text { cpit-1 }-0,223 \text { cpit-3, } \\
& \quad(2,8) \quad(14,5) \quad(2,5) \\
& \mathrm{s}=0,00656 .
\end{aligned}
$$

Pegar summa stika cpit-1 og cpit-3 er pvinguð til að vera 1 svo að röðin sé I(1) fæst 


$$
\begin{aligned}
& c p i_{t}=0,0037+1,301 c p i_{t-1}-0,301 c p i_{t-3}, \\
& (2,3) \quad(16,1 \quad(3,7)
\end{aligned}
$$

$\mathrm{s}=0,00672$.

Samkvæmt F-prófi á pvinguninni má hafna henni með $\mathrm{P}=0,067$ sem er í góðu samræmi við pá vitneskju að verðraðir falla hvorki vel að skilgreiningum I(1) né I(2) raða, heldur ættu pær heima einhvers staðar par á milli.

Önnur I(1) útgáfa:

$$
\Delta \text { cpit }=0,0048+0,454 \Delta \text { cpit-1, }
$$

$$
\mathrm{R}^{2}=0,184 ; \quad \mathrm{s}=0,00681 \text {. }
$$

Engin merki eru um eiginfylgni í frávikum ofangreindra jafna. Pau falla hins vegar á normaldreifingarprófi sem dregur úr gildi annarra frávikaprófa og prófum á stikum. Раð dregur hinsvegar ekkert úr gildi samanburðar á staðalfrávikinu við verðbólgujöfnu QMM í útgáfunni frá 2009. 
68 Tímarit um viðskipti og efnahagsmál 